\title{
Five new Caloplaca species (Teloschistaceae, Ascomycota) from Australia
}

\author{
Sergij Y. Kondratyuk ${ }^{1}$, John A. Elix ${ }^{2}$, Ingvar Kärnefelt ${ }^{3} \&$ Arne Thell $^{3}$ \\ ${ }^{1} \mathrm{M}$. H. Kholodny Institute of Botany, Tereshchenkivska Str. 2, 01601 Kiev, Ukraine. \\ E-mail: ksya_net@ukr.net \\ ${ }^{2}$ Research School of Chemistry, Building 33, Australian National University, Canberra, ACT 0200, Australia. \\ E-mail: john.elix@anu.edu.au \\ ${ }^{3}$ Botanical Museum, Lund University, Box 117, SE-22100 Lund, Sweden. \\ E-mail: ingvar.karnefelt@biol.lu.se, arne.thell@biol.lu.se
}

\begin{abstract}
Five new species of Caloplaca, C. mallacootensis, C. montenegrensis, C. rexii, C. rossii, and C. subgyalectoides are described, illustrated and compared with closely related taxa.
\end{abstract}

\section{INTRODUCTION}

According to a recent list, the genus Caloplaca Th. Fr. s. lat. includes 124 species in Australia (Kondratyuk et al., 2012). However, new species are continuing to be discovered and five additional species are described below.

\section{MATERIAL AND METHODS}

The study is based on collections, housed in Australian herbaria (CANB, MEL, PERTH, HO), lichen herbarium of the Botanical Museum in Lund (LD) and the lichen herbarium of M.H. Kholodny Institute of Botany of National Academy of Sciences of Ukraine (KW-L). Descriptions are based on hand-cut sections of the ascomata examined at high-power with a light microscope. Mounting media included water and $15 \% \mathrm{KOH}$. Measurements given in the descriptions of apothecial tissues, asci and ascospores are based on mounts in water only. Additional set of measurements for ascospores and ascospore septa is provided for $15 \% \mathrm{KOH}$ too. Measurements of ascospores and ascospore septa are based on 50-100 observations for each species (for each of both mounting media) and are presented in the form $5^{\text {th }}$ percentile- $95^{\text {th }}$ percentile; outlying values are given in brackets. The chemistry of the new species was determined using high performance liquid chromatography (Elix et al., 2003).

\section{DESCRIPTIONS OF TAXA}

Caloplaca mallacootensis S.Y. Kondr. \& Kärnefelt sp. nova

MycoBank No. - MB 804745

Similar to Caloplaca conranii, but differs in having whitish, flat and very often indistinct areoles, numerous oil cells in the paraphyses, broader ascospores with wider ascospore septa.

Type - Australia, Victoria, $3 \mathrm{~km}$ SW of Mallacoota, $98 \mathrm{~km} \mathrm{~S}$ of Bega, on coastal rocks, $37^{\circ} 34^{\prime} 28^{\prime \prime} \mathrm{S}, 149^{\circ} 45^{\prime} 58^{\prime \prime} \mathrm{E}$, growing together with Caloplaca eos and C. bartlettii (isotype LD), 11.11.1997, I. Kärnefelt 977205 (CANB - holotype, HO, LD - isotypes).

Description - Thallus usually indistinct or only the numerous apothecia apparent, areoles 0.4-0.7 mm wide, usually indistinct, scattered and discrete, whitish grey, rarely with yellow spots, possibly apothecial initials, with a rough, sometimes verruculose surface, often covered by algae and/or dust.

Apothecia numerous, scattered, rarely aggregated, usually rounded, strongly pronounced, 0.3-1 $\mathrm{mm}$ diam., and c. $0.3 \mathrm{~mm}$ thick, lecanorine to distinctly zeorine, thalline exciple white or whitish yellow to greenish yellow, often crenulate, usually seen from the side or below, very narrow, to $50 \mu \mathrm{m}$ thick in the lateral portion; true exciple slightly brighter than the disc, yellow orange, to $50 \mu \mathrm{m}$ thick; disc usually plane but 
sometimes concave, deep yellow, dull yelloworange or dull brownish orange; in section zeorine, thalline exciple 50-90 $\mu \mathrm{m}$ thick, with a well developed paraplectenchymatous cortical layer, true exciple very narrow, 20-25 $\mu$ m wide in the uppermost and lower lateral portions and 30-40 $\mu \mathrm{m}$ wide in basal portions, subhymenium $50-70$ $\mu \mathrm{m}$ thick, without oil droplets; hymenium 80-90 $\mu \mathrm{m}$ high, paraphyses insignificantly swollen towards tips, c. $2-3 \mu \mathrm{m}$ diam., with numerous ellipsoid or bifusiform, wide, bermaguiana-type oil cells (Kondratyuk et al., 2007), 6-8 $\mu \mathrm{m}$ diam., often 2 cells present in the same paraphyse; asci 2-8-spored, often 2, 4 or 6 mature bipolar together with several aborted ascospores per ascus; ascospores ellipsoid with somewhat attenuated ends, $(11-) 13-14(-16) \times 6-7 \mu \mathrm{m}$ in water, (11-)13-15(-16) × (6-)7.5-8(-9) $\mu \mathrm{m}$ in $\mathrm{K}$, septa (5-)6-7 $\mu \mathrm{m}$ wide in water, (4-)6-7.5(-8) $\mu \mathrm{m}$ wide in K. Pycnidia not seen.

Chemistry - Thallus $\mathrm{K}$-, epihymenium and outermost portions of true exciple $\mathrm{K}+$ brownish purple, uppermost cells of paraphyses stay reddish in $\mathrm{K}$.

Distribution and habitat - Known from several localities in eastern and southeastern Australia and New Zealand. On coastal rocks.

Etymology - The species epithet refers to the type locality in Victoria.

Additional specimens examined - Australia. New South Wales: Meribula Wharf and Aqaurium, Meribula, ca. $20 \mathrm{~km} \mathrm{SE}$ of Bega, 3654'23"S, 149 $55^{\circ} 41^{\prime \prime} \mathrm{E}$, on [siliceous] coastal rocks together with Caloplaca gallowayi, 10.11.1997, Kärnefelt 977004 (CANB, LD); $100 \mathrm{~km} \mathrm{~S}$ of Brisbane, $9 \mathrm{~km}$ S of Kingscliff, Norries Head, 28 20'09"S, 153³4'51'E, 27.10.1997, Kärnefelt 973304 (LD). Victoria: Wye River, $16 \mathrm{~km}$ S of Lorne, on the Great Ocean Road, 38 38'24"S, 14353'36"E, on coastal rocks together with C. gallowayi, 16.11.1997, Kärnefelt 978701 (LD, MEL); Port Fairy, western part of the shore, $29 \mathrm{~km}$ W of Warrnambool, 38 $23^{\prime} 54^{\prime \prime} \mathrm{S}$, $142^{\circ} 13^{\prime} 41^{\prime \prime} \mathrm{E}$, on coastal rocks near the sea, growing together with C. gallowayi, 14.11.1997, Kärnefelt 978204 (LD) (Fig. 1); Lorne, southern end of the town on the Great Ocean Road, on coastal rocks, 38 33'01'S, 14359'07'E, 16.11.1997, Kärnefelt 978801 (LD). - Tasmania: Tinderbox Road, $2^{\text {nd }}$ stop, seashore, $43^{\circ} 02 ' \mathrm{~S}, 147^{\circ} 18^{\prime} \mathrm{E}$, 0-9 $\mathrm{m}$ alt., on sandstone, sheltered and rare, 02.10.1966, Bratt \& Cashin 3539 (HO 38781 mounted in the same packet with Caloplaca sublobulata, C. gallowayi and C. cribrosa); Lune River Lagoon mouth, $43^{\circ} 26^{\prime} \mathrm{S}, 146^{\circ} 54^{\prime} \mathrm{E}$, on dolerite, exposed and common, growing together with C. sublobulata, 06.07.1968, Bratt \& Cashin 68/521 (HO 41238). - New Zealand. South Island: Otago, S of Dunedin, close to Nugget Point, $46^{\circ} 25.49^{\prime} \mathrm{S}, 169^{\circ} 47.70^{\prime} \mathrm{E}$, growing on coastal rocks, locally abundant, 05.02.1999, Kärnefelt 998301 (LD); Otago, Old Man Range, N of Roxbough, on the road to Obelisk, $45^{\circ} 20.15^{\prime} \mathrm{S}, 169^{\circ} 16.16^{\prime} \mathrm{E}$, c. $700 \mathrm{~m}$ alt., on shaded schist rocks, 07.02.1999, Kärnefelt 999002 (LD); North Island: N of Wellington, Pukerua Bay, $41^{\circ} 01.55^{\prime} \mathrm{S}, 144^{\circ} 54.11^{\prime} \mathrm{E}$, on coastal rocks, growing together with C. jackelixii, 13.02.1999, Kärnefelt 9910601 (LD).

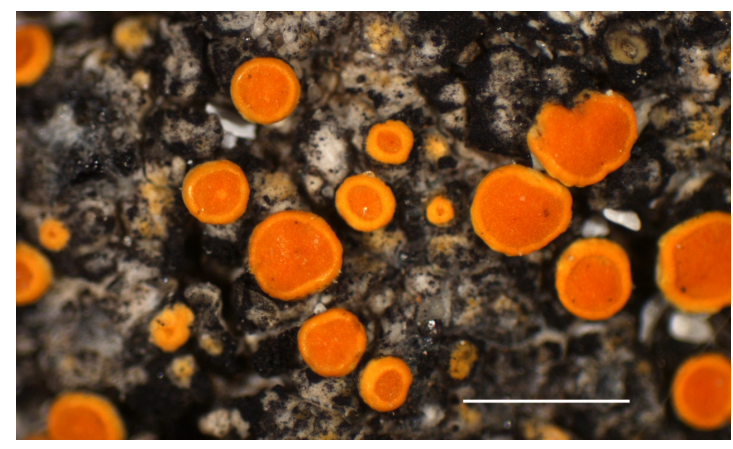

Fig. 1. Caloplaca mallacootensis, general habit (I. Kärnefelt 978204 - LD). Scale 1 mm.

Taxonomic notes - Caloplaca mallacootensis is characterized by the strongly pronounced zeorine apothecia with deep yellow to yellow-orange or orange-brown discs situated on indistinct or scattered areoles.

C. mallacootensis is similar to C. conranii S. Y. Kondr. \& Kärnefelt and C. holocarpa (Hoffm.) Wade, another species with large orange apothecia but with better developed thalli. The oil cells in the paraphyses are frequent in $C$. mallacootensis, but absent in C. holocarpa. The ascospores are narrower in C. conranii (5-6 $\mu \mathrm{m}$ versus 6-7 $\mu \mathrm{m}$ in C. mallacootensis) and the septa wider (Kondratyuk et al. 2007). Caloplaca holocarpa has even longer ascospores (13-14 $\mu \mathrm{m})$ and broader septa (Kondratyuk et al., 2004). C. mallacootensis is also similar to the coastal European species C. navasiana Nav.-Ros. \& Cl. Roux, C. lactea s.str., and North American coastal C. luteominia (Tuck.) Zahlbr. However, C. mallacootensis differs from these species in having larger apothecia, longer ascospores and much wider ascospore septum.

\section{Caloplaca montenegrensis S.Y. Kondr. \& Kärnefelt sp. nova}

MycoBank No. - MB 804746;

syn. Caloplaca montisnegro herb. name.

Similar to Caloplaca cerinelloides but differs in 
having typically biatorine apothecia, in having markedly widened, slightly brownish oil cells in the middle and upper positions of paraphyses and 1-4(-6)-spored asci.

Type - South Australia, $8 \mathrm{~km} \mathrm{~S}$ of Black Hill township, mallee scrub, on Leptospermum shrubs, 29.10.1981, J. A. Elix 9361, (CBG 9600389 - holotype, B - isotype) (Fig. 2).

Description - Thallus 0.5-6 cm wide, formed by numerous micro-warts, granules or areoles, $0.2-0.4 \mathrm{~mm}$ wide, scattered in crevices of the substrate, generally indistinct and seen only at the base of the apothecia, brownish greenish or yellowish grey, with numerous, bright yellow to dull yellow brownish apothecia scattered over the thallus.

Apothecia very small, usually numerous, scattered, concave at first then plane, $0.2-0.4(-0.5)$ $\mathrm{mm}$ diam. and $0.18-0.28 \mathrm{~mm}$ thick, becoming biatorine or zeorine, with dull yellow to dull brownish orange discs, matt, sometimes with very scarce whitish pruina, true exciple distinct, pronounced, bright to dull yellow, 0.05-0.07 $\mathrm{mm}$ thick, thalline exciple becoming excluded, seen merely at the base of the apothecia, somewhat brownish to greenish grey or dull brownish white; in section zeorine, thalline exciple 50-80 $\mu \mathrm{m}$ wide, cortical layer not developed or to 20 $\mu \mathrm{m}$ thick with an epinecral layer 7-10 $\mu \mathrm{m}$ thick, usually with dust crystals; algal layer below true exciple to $40 \mu \mathrm{m}$ thick, broad, often reaching mid-hymenium level in the lateral portion; true exciple 20-40(-50) $\mu \mathrm{m}$ thick in the uppermost lateral portion, with thick walled rounded cells 5-6 $\mu \mathrm{m}$ diam., and 10-20(-30) $\mu \mathrm{m}$ thick in the lower lateral and in basal portion, sometimes not seen in basal portion, paraplectenchymatous; hymenium 55-60(-70) $\mu \mathrm{m}$ high, hyaline; epihymenium 5-7(-12) $\mu$ m thick, somewhat greenish orange to brownish orange due to numerous

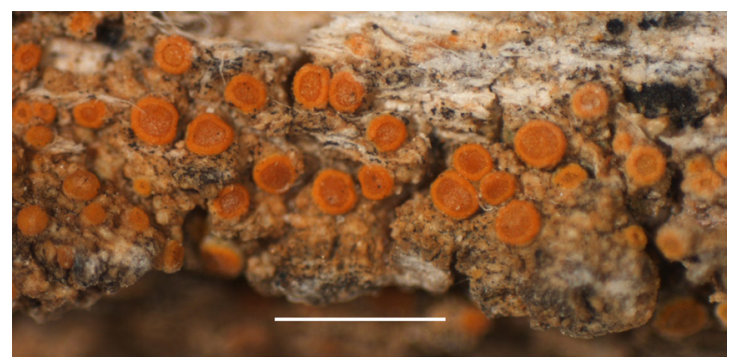

Fig. 2. Caloplaca montenegrensis, general habit (CANB - holotype). Scale $1 \mathrm{~mm}$. oil cells; subhymenium thin, to $30 \mu \mathrm{m}$ thick, hyaline with scarse oil droplets, 2-6 $\mu \mathrm{m}$ diam.; paraphyses richly branched in the upper portion with long secondary branches, 15-20 $\mu \mathrm{m}$ long, becoming \pm broader towards the tips, $2-5(-7) \mu \mathrm{m}$ diam. (better seen in $\mathrm{K}$ ), with distinctly widened, vertically elongated oil cells (1-2 or more), usually present in the middle part of the paraphyses, 5-8(-9) $\mu \mathrm{m}$ wide, to $20 \mu \mathrm{m}$ and more below the apices, becoming brownish (better seen in K); asci 1-4(-6-8?)-spored; ascospores bipolar, hyaline, broadly ellipsoid with somewhat pointed or rounded ends and widened at the rather narrow septa, (9-)11-13(-14) × (5.5-)6-7(-8) $\mu \mathrm{m}$ in water, 10-14 × (6-)7-8(-9) $\mu \mathrm{m}$ in $\mathrm{K}$, septa 3-4(-5) $\mu \mathrm{m}$ wide in water, $3-5(-6) \mu \mathrm{m}$ wide in $\mathrm{K}$. Hyaline, aborted ascospores of various size are frequently seen. Pycnidia not seen.

Chemistry - epithecium and uppermost portion of true exciple $\mathrm{K}+$ dark brownish purple (reaction sometimes slow), fading over time but the epithecium remains crimson-violet. Constituent: parietin (major).

Ecology - Grows on twigs of various shrubs.

Distribution - Western and South Australia.

Etymology - The species epithet refers to the type locality.

Additional specimens examined - Australia. Western Australia: $44 \mathrm{~km}$ W of Mullewa, E of Geraldton, along the Mullewa-Geraldton road, $28^{\circ} 41^{\prime} 46^{\prime \prime} \mathrm{S}$, $115^{\circ} 06^{\prime} 53^{\prime \prime E}$, open scrub (Acacia acuminata, Eucalyptus sp.) with sandstone, on bark growing together with Jackelixia elixii, 07.01.2004, S. Kondratyuk 20428, I. Kärnefelt \& R. Cranfield (KW); Shark Bay, Useless Loop townsite, on beach front facing $\mathrm{E}$, on dead Acacia shrubs, growing together with Caloplaca subgyalectoides, 20.01.1983, N. Sammy s.n., (PERTH 2814544). South Australia: Fleurieau Peninsula, Port Elliot, on wood, $10 \mathrm{~m}$ above the shore line, $35^{\circ} 32.23^{\prime} \mathrm{S}$, $138^{\circ} 40.90^{\prime} \mathrm{E}, 20.01 .1999$, I. Kärnefelt 995604 (LD); $18.3 \mathrm{~km}$ ENE of Kimba, on low bushes, growing together with Caloplaca bastowii, 27.09.1965, Beauglehole 15120, 15120A (MEL 27915, 27914).

Taxonomic notes: Caloplaca montenegrensis is similar to C. cerinelloides (Erichson) Poelt but differs in generally having biatorine apothecia, in having markedly broadened tips of the paraphyses, and distinct, very broad oil cells in the middle and upper positions of paraphyses which become slightly brownish, and 1-4(-6)-spored asci.

Caloplaca montenegrensis is also similar to $C$. aegatica Giralt, Nimis \& Poelt and C. raesaenenii Bredk., which may also grow on shrubs (Kon- 
dratyuk et al., 2004). However it differs from the latter species in having different thallus and thalline exciple, as well as in having different measurements of ascospores and much wider ascospore septum.

C. montenegrensis is also similar to C. pyracea (Ach.) Th. Fr. but differs in having a microwarted thallus, a better developed proper margin, very broad oil cells in the paraphyses which become distinctly brownish in $\mathrm{K}$, as well as in its distribution (C. pyracea occurs in the Northern Hemisphere, see Kondratyuk et al., 2004).

\section{Caloplaca rexii S.Y. Kondr. \& Kärnefelt sp. nova}

MycoBank No. - MB 804747

Similar to Caloplaca rubelliana, but differs in having distinctly raised apothecia, longer and narrow ascospores as well as in lacking a well developed thallus.

Type - Australia, New South Wales, the upper end of Mootwingee gorge, Mootwingee National Park, 23.10.1991, R. Filson 20010 (CANB holotype) (Fig. 3).

Description - Thallus 5-10 mm wide, composed of brown, aggregated apothecia forming extended patches. Relatively thick, small areoles rarely visible, c. $0.5-0.7(-1.5) \mathrm{mm}$ wide with an extremely uneven, somewhat eroded, cracked and exfoliating surface, whitish grey to dark grey or bluish grey near the apothecia. Prothallus absent.

Apothecia very numerous, densely aggregated and usually crowded, irregular in shape due to mutual pressure, elevated on long stipes, (0.2-)0.4-0.8(-1) mm diam., 0.25-0.3 mm thick,

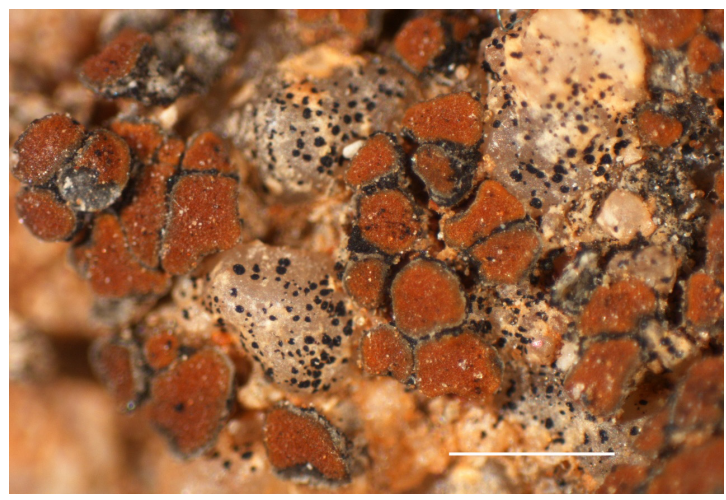

Fig. 3. Caloplaca rexii, general habit (CANB holotype). Scale $1 \mathrm{~mm}$. stipes to $0.3 \mathrm{~mm}$ high, biatorine or zeorine, thalline margin dull brownish orange with bluish grey or whitish grey to bluish brown or brownish green, seen only at the side or base of apothecia, proper margin \pm slightly shiny, $0.05-0.07 \mathrm{~mm}$ wide, concolorous with the disc; thalline exciple with a c. $30 \mu \mathrm{m}$ thick cortical layer, more visible in $\mathrm{K}$; proper exciple $50-100(-120) \mu \mathrm{m}$ wide in the uppermost lateral portion and 10-20(-50) $\mu \mathrm{m}$ thick in the lower lateral and 25-35 $\mu \mathrm{m}$ thick in basal portion, paraplectenchymatous to pseudoprosoplectenchymatous, cell lumina 2-3 $\mu \mathrm{m}$ wide cf. 'textura intricata'; hymenium 70-90(-100) $\mu \mathrm{m}$ high; subhymenium (50-)100$150 \mu \mathrm{m}$ thick, hyaline, without oil droplets; paraphyses slightly swollen towards the tips, 3-4 $\mu \mathrm{m}$ diam., richly branched, secondary branches rather short; asci 8-spored, abortive ascospores sometimes present; ascospores long and narrow, slightly swollen at the septum, (12-)14-18(-19) $\times 4-5(-7) \mu \mathrm{m}$ in water, $14-18(-21) \times(4-) 5-7(-8)$ $\mu \mathrm{m}$ in $\mathrm{K}$; septum rather narrow, $2-4 \mu \mathrm{m}$ wide in water and $(2-) 3-4(-5) \mu \mathrm{m}$ wide in K. Pycnidia not seen.

Chemistry: epihymenium $\mathrm{K}-$, content of ascospores $\mathrm{K}+$ reddish; containing parietin (major), emodin (minor/trace), fallacinal (minor/trace), teloschistin (minor), parietinic acid (trace), erythroglaucin (minor).

Distribution and habitat - Known from scattered localities in New South Wales and New Zealand. This species occurs on siliceous rocks, often associated with the Caloplaca subsoluta aggr. Etymology - The species is named after the Australian lichenologist, Rex Filson, who collected the type specimen.

Additional specimen examined - New Zealand: Otago, North Otago Botanical district, Cromwell, rocks at the railway station, growing together with Caloplaca rubelliana [as holotype of Caloplaca amylacea H. Magn.], 17.03.1927, G. E. \& G. Du Rietz 2178a: 8 (UPS 84530 (L49190)).

Taxonomic notes: Caloplaca rexii resembles $C$. rubelliana (Ach.) Lojka, but differs in having more pronounced apothecia, a more rudimentary thallus and longer and narrower ascospores. Two Northern Hemisphere species, C. arenaria (Pers.) Müll. Arg. and C. percrocata (Arnold) Steiner, are morphologically similar. However, C. rexii differs from $C$. arenaria in having much longer ascospores, and wider septa (exceeding $2 \mu \mathrm{m}$ ), whereas C. percrocata has smaller ascospores than $C$. rexii. 
From Caloplaca scotoplaca (Nyl.) H. Magn. occurring in the Northern Hemisphere, C. rexii differs in having larger apothecia, in having longer and narrower ascospores, and in having narrower ascopore septum as well as in the lack of reddish colour of apothecium disc.

\section{Caloplaca rossii S.Y. Kondr. \& Kärnefelt sp. nova}

MycoBank No. - MB 804748

Similar to Caloplaca leptozona but differs in having a distinctly areolate thallus, biatorine apothecia which soon become convex and black margined, and dull yellow-brown to blackish discs, as well as much larger ascospores with wider septa.

Type - Australia, Northern Territory, Arnhem Land, Brogden Point, $11^{\circ} 34^{\prime} \mathrm{S}, 133^{\circ} 04^{\prime} \mathrm{E}$, growing on cliff overlooking the Arafura Sea, $20 \mathrm{~m}$ alt., 27.08.1987, J. H. Ross 3282 (MEL 2043375 - holotype, CANB, LD - isotypes) (Fig. 4).

Description - Thallus 5-10 cm wide but sometimes forming larger patches, distinctly areolate; areoles 0.2-0.5(-0.9) $\mathrm{mm}$ wide, very irregular, angular, scattered to aggregated, whitish grey, sometimes with blackish edges, closely attached to the substrate, becoming thinner towards the tips; prothallus usually absent, when present forming a blackish rim to $0.8 \mathrm{~mm}$ wide.

Apothecia usually scattered, rarely aggregated in smaller group, initially immersed then sessile, matt, rarely with a sparse whitish pruina, plane then convex, 0.2-0.5(-0.6) $\mathrm{mm}$ diam. and $0.3 \mathrm{~mm}$ thick, usually biatorine with blackish margin and yellowish brown to black disc, rarely zeorine with a thalline margin concolorous with

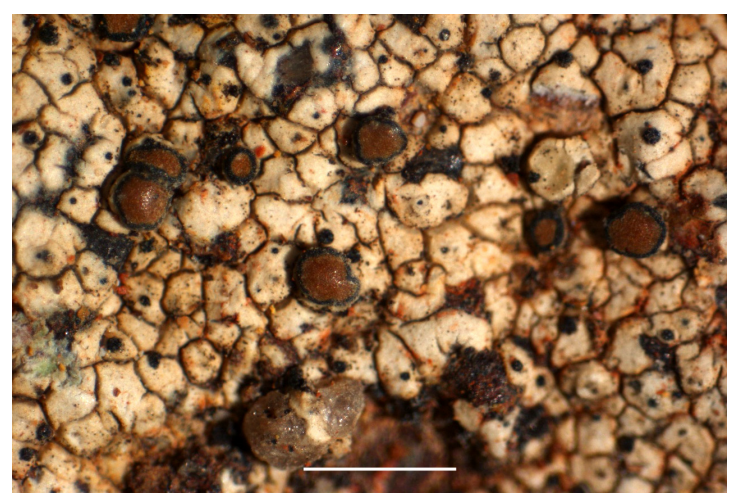

Fig. 4. Caloplaca rossii, general habit (MEL holotype). Scale $1 \mathrm{~mm}$. the thallus; in section biatorine, thalline exciple absent and algae only present in the stipe of the apothecium; proper exciple to $50 \mu \mathrm{m}$ wide in the uppermost and lower lateral portions, the outer layer 20-30 $\mu \mathrm{m}$ thick, greenish or bluish black, of palisade plectenchyma, basal portion 70-100(-120) $\mu \mathrm{m}$ thick, hyaline or becoming brownish or orange-brown, pseudoprosoplectenchymatous with well developed matrix and cell lumina 2-3 $\mu \mathrm{m}$ diam.; hymenium 60-70 $\mu \mathrm{m}$ high; subhymenium 50-70 $\mu \mathrm{m}$ thick, hyaline to straw-coloured due to the presence of oil droplets or irregular aggregations; asci 8-spored, often with only 2, 4 or 6 well developed, mature bipolar ascospores together with simple or 1-septate aborted spores, mature ascospores broadly ellipsoid with somewhat rounded ends, rarely fusiform with slightly attenuated ends, thickened at the septa, [8-](10-)12-13(-14) $\times$ (4.5-)5.5-6.5(-7) $\mu \mathrm{m}$ in water and (11-)12-15(18) $\times 6-8(-10) \mu \mathrm{m}$ in $\mathrm{K}$, septa (3-)5-7(-9) $\mu \mathrm{m}$ wide in water and (4-)6-10(-11) $\mu \mathrm{m}$ wide in $\mathrm{K}$. Pycnidia with well developed conidia not seen. Chemistry - Thallus $\mathrm{K}+$ yellow, outermost greenish bluish black portion of the uppermost lateral portion of true exciple $\mathrm{K}-$, epihymenium $\mathrm{K}+$ purple; containing parietin (minor), atranorin (major), caloploicin (major or minor), vicanicin (minor), chloroatranorin (trace), fulgidin (trace), isofulgidin (trace), diploicin (trace).

Distribution and habitat - The species is known from a number of localities in Western Australia and Northern Territory where it grows on siliceous rocks.

Etymology - Caloplaca rossi is named after the Australian vascular plant botanist, J. H. Ross, who provided the rich type collection of this new species.

Additional specimens examined - Australia. Western Australia: North Kimberleys, Drysdale River National Park, Carson Escarpment, ca. $40 \mathrm{~km} \mathrm{~S}$ of Carson River Homestead, growing on shaded walls of a ravine together with Peltula euploca, 10.06.1984, J. H. Willis s.n. (MEL 1050513); Kimberley Region, Kununurra, Hidden Valley National Park, 100 m N of car park area, $15^{\circ} 45^{\prime} 56^{\prime \prime} \mathrm{S}, 128^{\circ} 45^{\prime} 02^{\prime \prime} \mathrm{E}$, sheltered sandstone rockface, S facing, 29.06.1997, K. Ralston 301 (MEL 2043420); Fitzgerald Region, Kimberley, Silent Grove, Bell Creek, Mt Hart Station, $17^{\circ} 00^{\prime} \mathrm{S}$, $125^{\circ} 12^{\prime} \mathrm{E}$, growing on rock, S facing above creek, vegetation dominated by Ficus and Pandanus sp., Caloplaca rossii growing together with C. cupulifera, 12.08.1997, K. Ralston 300 (MEL 2043418); East Kimberley Region, Kulumburu Road, 25-50 m south of Gibb River Crossing, $16^{\circ} 05^{\prime} 54^{\prime \prime S}, 126^{\circ} 30^{\prime} 37^{\prime \prime} \mathrm{E}$, 
06.08.1997, K. Ralston 308 (MEL 2043424); East Kimberley Region, Gibb River Road, El Questro Gorge, El Questro Station, $16^{\circ} 01^{\prime} 30^{\prime \prime S}, 128^{\circ} 01^{\prime} 22^{\prime \prime} \mathrm{E}$, $\mathrm{S}$ facing sandstone rock face above creek, dominated by Livistonia eastonii palms, 01.08.1997, K. Ralston 303, 305 (MEL 2043421, MEL 2043413); Purnululu (Bungle Bungles) National Park, $1.5 \mathrm{~km}$ S of car park, $17^{\circ} 19^{\prime} 43^{\prime \prime} \mathrm{S}, 128^{\circ} 23^{\prime} 51^{\prime \prime} \mathrm{E}$, growing on conglomerate rock, shaded cliff area dominated by Livistonia palms (Mini Palm walk), 23.09.1997, K. Ralston 297 (MEL 2043415). - Northern Territory: Gregory National Park, side gorge, plateau edge, c. $29 \mathrm{~km}$ NW of Bullita Outstation, $400 \mathrm{~m}$ from head of gorge, $15^{\circ} 57^{\prime} 00^{\prime \prime} \mathrm{S}$, $130^{\circ} 13^{\prime} 44^{\prime \prime} \mathrm{E}$, sandstone/quartz site plateau, boggy area, 15.04.1996, Coles 154 (MEL 1033373), Coles 159 (MEL 1033371); Kakadu National Park, Ubirr, Bardedjilidjii sandstone cliffs, in open, dry monsoonforest, $80 \mathrm{~m}$ alt., $12^{\circ} 26^{\prime} \mathrm{S}, 132^{\circ} 58^{\prime} \mathrm{E}, 23.08 .1995, \mathrm{~K}$. $\&$ A. Kalb (herb. K. Kalb 29578); Keep River National Park, Nganlong Track, $200 \mathrm{~m}$ N of Aboriginal Site, $15^{\circ} 48^{\prime} \mathrm{S}, 129^{\circ} 06^{\prime} \mathrm{E}$, rock, S facing, 22.07.1997, K. Ralston 295 (MEL 2043425); Keep River National Park, 'Western Walk' from Jarrnarm Camping area, $15^{\circ} 45^{\prime} \mathrm{S}$, $129^{\circ} 05^{\prime} \mathrm{E}, \mathrm{N}$ facing, shaded, sandstone, 21.07.1997, $K$. Ralston 310 (MEL 2043423); Keep River National Park, 'Western Walk' from Jarrnarm Camping area, $15^{\circ} 45^{\prime} \mathrm{S}$, $129^{\circ} 05^{\prime} \mathrm{E}$, sandstone rockface ('Kelly's Knobs'), Gorge running north-south, rock facing E, 21.07.1997, $K$. Ralston 302 (MEL 2043419); type locality, 27.08.1987, J. H. Ross 3283C (MEL 2043374).

Taxonomic notes - Caloplaca rossii is similar to C. leptozona but differs in having a distinctly areolate thallus, biatorine apothecia which soon become convex and have a black margin and dull brown yellow to blackish disc, as well as larger ascospores $(12-13 \times 5.5-6.5 \mu \mathrm{m}$ vs. $10-11 \times 4-5.5 \mu \mathrm{m})$, and broader septum $(5-7$ $\mu \mathrm{m}$ vs. $4-5.5 \mu \mathrm{m})$.

C. rossii is also similar to the widely distributed tropical species, C. poliotera (Nyl.) J. Steiner, but differs in having a much thicker, continuous, non-areolate, $\mathrm{K}$ - or $\mathrm{K}+$ slowly brownish yellow thallus, in having distinctly immersed apothecia and slightly longer ascospores with wider septa (3-4 $\mu \mathrm{m}$ wide in C. poliotera).

\section{Caloplaca subgyalectoides S.Y. Kondr. \& Kärnefelt, sp. nova}

\section{MycoBank No. - MB 804749}

Similar to Caloplaca gyalectoides but differs in having smaller apothecia, a much narrower thalline exciple, a paraplectenchymatous true exciple, and longer ascospores, as well as in lacking a thick necrotic zone forming bundles of parallel hyphae projecting from the proper exciple.
Type - Western Australia, near Carnamah, E edge of Yarra Yarra Lake, 29 45'36"'S, $115^{\circ} 51^{\prime} 42^{\prime \prime} \mathrm{E}$, on twigs of Halsarcia, growing together with Caloplaca yarraensis, 04.01.2004, S. Y. Kondratyuk 20413, I. Kärnefelt \& R. J. Cranfield (PERTH - holotype, CANB, HO, KW, LD - isotypes) (Fig. 5).

Description - Thallus 1-2(-3) $\mathrm{mm}$ wide, forming dark greyish or greenish grey verruculae or whitish crustose in part, verruculose portions present among dense aggregations of apothecia, from thin and indistinct to rather thick or subconvex, young apothecia often immersed in the thallus. Prothallus absent.

Apothecia usually numerous, densely aggregated, rarely scattered, initially immersed then distinctly sessile, more or less plane, (0.2-)0.3$0.5(-0.8) \mathrm{mm}$ diam. and $0.27-0.3 \mathrm{~mm}$ thick, usually biatorine, proper margin concolorous with disc, slightly elevated, rarely zeorine with a somewhat greenish thalline exciple visible from the side or below, disc dull yellow, yellow brownish or yellow-pink with a whitish pruina, particularly marked on juvenile apothecia; in section zeorine, thalline exciple well developed, 100-120 $\mu \mathrm{m}$ thick, with a very thin cortical layer of algal plectenchyma, $10-20 \mu \mathrm{m}$ thick; proper exciple $50-70 \mu \mathrm{m}$ thick in the uppermost lateral portion, 15-30 $\mu \mathrm{m}$ thick in the lower lateral and basal portion, distinctly paraplectenchymatous, with rounded to ellipsoid cell lumina, 3-5 $\mu \mathrm{m}$ wide; algal zone to $90 \mu \mathrm{m}$ thick, continuous with rather large algal cells, 25-29 $\mu \mathrm{m}$ diam.; hymenium 60-70 $\mu \mathrm{m}$ high; epihymenium 15-20 $\mu \mathrm{m}$ thick, yellowish brown with a tint of green; paraphyses with distinctly swollen tips, to $5 \mu \mathrm{m}$ diam., with numerous oil cells, cells spherical to slightly clavate, 6-8 $\mu \mathrm{m}$ diam., with somewhat granular contents visible in $\mathrm{K}$; subhymenium 30-50 $\mu \mathrm{m}$ thick, hyaline, without oil droplets; asci 8-spored; ascospores very variable, broadly ellipsoid with rounded ends to somewhat fusiform with attenuated ends and slightly thickened at the septa, ([9-]11-)12-14 × (5-)6-7 $\mu \mathrm{m}$ in water and (9-)11-14 × (5-)6-8(-9) $\mu \mathrm{m}$ in $\mathrm{K}$, septa (2-)2.5-3.5 $\mu \mathrm{m}$ wide in water and 3-4(-5) $\mu \mathrm{m}$ in K. Pycnidia not seen.

Chemistry - Epihymenium $\mathrm{K}+$ deeply reddish or dirty purple sometimes blackish purple in places. Constituent: parietin (major).

Distribution and habitat - Scattered in Western Australia. On twigs of shrubs.

Etymology - The name reflects the similarity of 

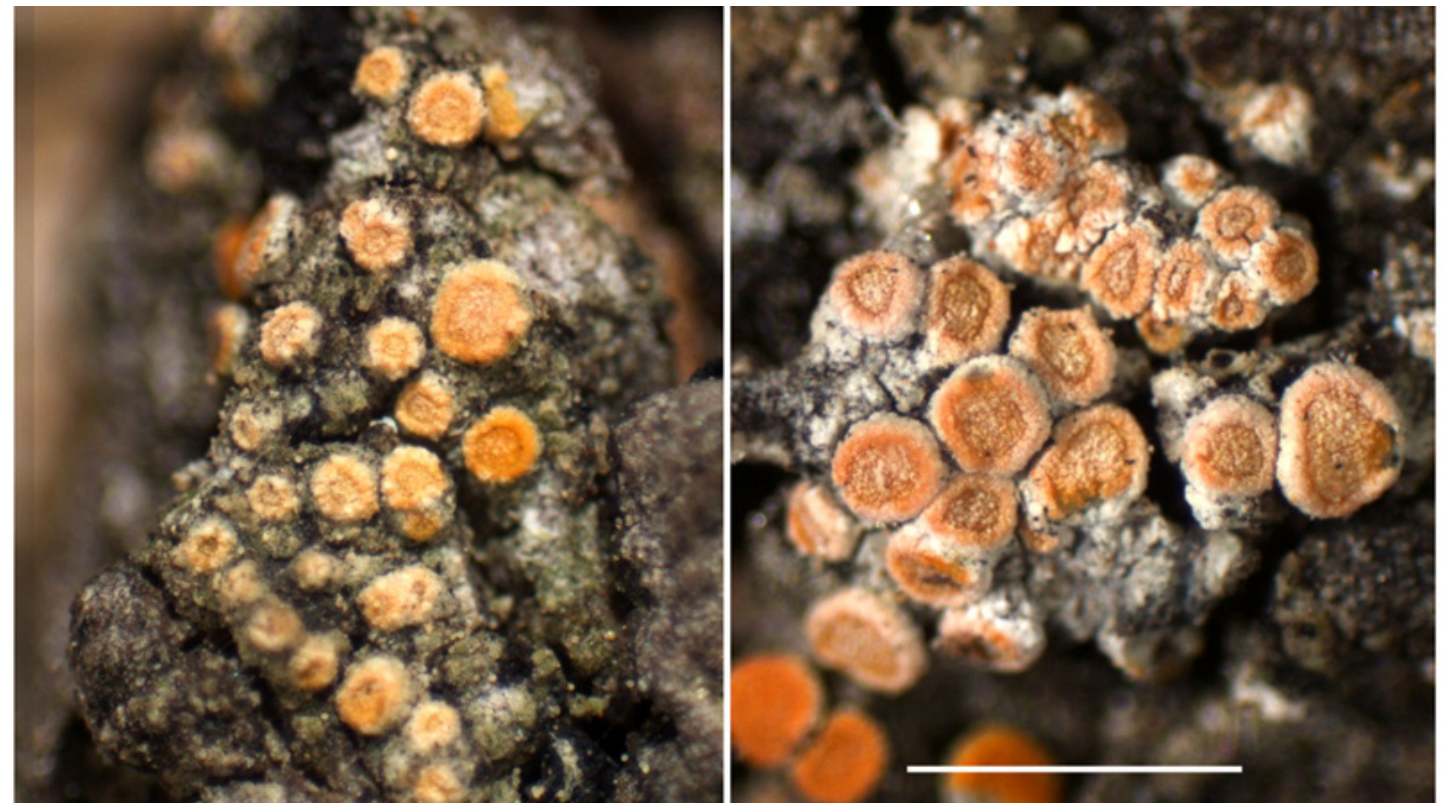

Fig. 5. Caloplaca subgyalectoides, general habit (CANB - isotype). Scale $1 \mathrm{~mm}$.

this new species to the African taxon, Caloplaca gyalectoides S.Y. Kondr. \& Kärnefelt.

Additional specimen examined - Australia. Western Australia: Lake King on $\mathrm{S}$ side of road at $\mathrm{E}$ and of Lake, $33^{\circ} 05^{\prime} \mathrm{S}, 119^{\circ} 40^{\prime} \mathrm{E}$, in salt lake, on stems of aff. Pachycornia tenuis (Sclerostegia moniliformis), growing together with Caloplaca hnatiukii S. Y. Kondr. \& Kärnefelt, 22.11.1976, R. Hnatiuk 761354 (PERTH 2810646 - holotype of Caloplaca hnatiukii). One more locality is cited under C. montenegrensis (see page 43).

Taxonomic notes - Caloplaca subgyalectoides is characterized by very small, densely aggregated pinkish yellow apothecia, with whitish pruina especially when juvenile, a variable greyish or greenish grey thallus, and in having rather large ascospores with a narrow septum. It appears to be restricted to the salt lake areas of Western Australia.

Caloplaca subgyalectoides resembles C. gyalectoides S. Y. Kondr. \& Kärnefelt known from the Cape Province in South Africa, where it grows on dead shrubs in the dunes near the sea together with Xanthodactylon alexanderbaai, X. turbinatum, X. flammeum, and other endemic African lichens. However, C. subgyalectoides differs in having smaller, typically biatorine, densely aggregated apothecia to $0.5 \mathrm{~mm}$ wide, in contrast to the zeorine apothecia of $C$. gyalectoides which often exceed $2.0 \mathrm{~mm}$ diam. Additional distin- guishing characters in C. subgyalectoides are the narrower thalline exciple, a paraplectenchymatous rather than scleroplectenchymatous proper exciple, and longer ascospores (Kärnefelt et al., 2002).

Caloplaca subgyalectoides often grows together with two additional species characterized by narrow ascospore septa, C. hnatuikii and $C$. yarraensis S. Y. Kondr. \& Kärnefelt. C. subgyalectoides is distinguished from both these species by the dull yellow, yellow brownish or yellow-pink apothecia with a dense to sparse whitish pruina, and a very thin, greenish thalline exciple seen on sides of the apothecia. $C$. hnatiukii has apothecia of the C. pyracea-type with a yellow orange disc and a paler, yellowish own margin, and even narrower septa, 1-2(-3) $\mu \mathrm{m}$ wide. C. yarraensis has a poorly developed or evanescent thallus, biatorine, dull orange apothecia and shorter ascospores (10-12 $\mu \mathrm{m}$ long) with narrower septa, $2-3 \mu \mathrm{m}$ wide. According to our preliminary data, $C$. subgyalectoides differs from C. yarraensis also in DNA sequences.

\section{ACKNOWLEDGEMENTS}

We are thankful to Tiina Randlane and Jan Vondrák for valuable comments to our manuscript. 
SK and IK would like to express their gratitude to Drs N. \& D. Marchant (Como, WA), Ray J. Cranfield (Manjimup, WA), Prof. J. Elix and Dr. P. McCarthy (Canberra, ACT), and Dr. R. Filson (Booral, NSW) for kind support and hospitality during their field trip in 2004, and to Dr. N. Marchant and K. Sommerfield (Melbourne) for their assistance with loans and support.

\section{REFERENCES}

Elix, J. A., Giralt, M. \& Wardlaw, J. H. 2003. New chloro-depsides from the lichen Dimelaena radiata. Bibliotheca Lichenologica 86: 1-7.

Kärnefelt, I., Kondratyuk, S., Søchting, U., Frödén, P. \& Arup, U. 2002. Two new species of Caloplaca (Teloschistaceae) from the Southern Hemisphere. Bryologist 105(3): 301-309. http://dx.doi.org/10.1639/0007-2745(2002) 105[0301:TNSOCT]2.0.CO;2

Kondratyuk, S. Ya., Khodosovtsev, A. Ye., Oxner, A. N. 2004. Caloplaca. In: Khodosovtsev, A. Ye., Kondratyuk, S. Ya., Makarova, I. I. \& Oxner, A. N. (eds). Handbook of the lichens of Russia 9. Fuscideaceae, Teloschistaceae. Sankt-Peterburg, Nauka, pp. 38-236. (In Russian).

Kondratyuk, S. Ya., Kärnefelt, I., Elix, J. A. \& Thell, A. 2007. New species of the genus Caloplaca in Australia. In: I. Kärnefelt \& A. Thell (eds). Lichenological Contributions in Honour of David Galloway. Bibliotheca Lichenologica 95: 341-386.

Kondratyuk S. Y., Elix J. A., Kärnefelt I. \& Thell, A. 2012. An artificial key to Australian Caloplaca species (Teloschistaceae, Ascomycota). In: I. Kärnefelt, M. R. D. Seaward \& A. Thell (eds). Systematics, biodiversity and ecology of lichens. Bibliotheca Lichenologica 108: 141-160. 